7-1-2015

\title{
Michael Katz on Place and Space in Urban History
}

Timothy J. Gilfoyle

Loyola University Chicago, tgilfoy@luc.edu

Follow this and additional works at: https://ecommons.luc.edu/history_facpubs

\section{Recommended Citation}

Gilfoyle, Timothy J.. Michael Katz on Place and Space in Urban History. Journal of Urban History, 41, 4: 572-584, 2015. Retrieved from Loyola eCommons, History: Faculty Publications and Other Works, http://dx.doi.org/10.1177/0096144215579381

This Article is brought to you for free and open access by the Faculty Publications and Other Works by Department at Loyola eCommons. It has been accepted for inclusion in History: Faculty Publications and Other Works by an authorized administrator of Loyola eCommons. For more information, please contact ecommons@luc.edu. (c) (i) $\Theta \Theta$

This work is licensed under a Creative Commons Attribution-Noncommercial-No Derivative Works 3.0 License. (c) Sage Publications 


\title{
Michael Katz on Place and Space in Urban History
}

\section{Timothy J. Gilfoyle}

DOI: 10.1 |77/0096|4421557938|

\author{
Keywords \\ Lewis Mumford, race, religion, urban space, urbanization
}

Few will ever question the originality and pathbreaking importance of Michael Katz's many and influential publications. Fewer still will be surprised that "From Urban as Site to Urban as Place" raises creative and penetrating questions about the writing of urban history during the past half century. Katz's erudite essay typifies his scholarly oeuvre. Whether writing about education, geographic mobility and transiency, the persistence of urban poverty, historical sociology, urban disorder, or the multiple and profound intersection of these subjects, ${ }^{1}$ Michael Katz more often than not forces historians in multiple fields to not only reinterpret long-held paradigms but to revisit fundamental problems. Simply put, Katz asks questions that force us to reexamine how we think about cities.

Katz places considerable importance on the Yale University conference on urban history in 1968 that produced the influential volume Nineteenth-Century Cities (1969). ${ }^{2}$ The event proved to be a landmark gathering for a generation of urbanists who came of age at a paradoxical moment in American urban history: the simultaneous optimism embodied in the Great Society and economic abyss of the "urban crisis." These events combined to force many historians to reconceptualize their treatment of American cities. ${ }^{3}$ Before 1970, urban history was a field with a meta-narrative, exemplified in the writings of Arthur M. Schlesinger Sr. and Lewis Mumford. Schlesinger's seminal The Rise of the City, 1878-1898 (1933) moved the discussion of cities past the celebratory accounts of earlier booster biographies of cities while also challenging the popular frontier thesis of Frederick Jackson Turner. The city, not the frontier, was the central theme in the emergence of the modern United States. ${ }^{4}$ Significantly, Schlesinger emphasized the physical spaces and social structures found in cities, relying upon and integrating theories associated with the so-called Chicago School of Sociology. "There is a city mentality which is clearly differentiated from the rural mind," wrote Louis Wirth. "The city man thinks in mechanistic terms, in rational terms, while the rustic thinks in naturalistic, magical terms." 5 Schlesinger implicitly agreed and set the stage for later historians such as Richard Wade and John Reps who argued that the "American character" was historically rooted more in the American city than the Western frontier. 6

Writer and architectural critic Lewis Mumford repeated Schlesinger's portrait equating cities with civilization. In multiple publications after 1930 which culminated in The City in History

'Department of History, Loyola University Chicago, Chicago, IL, USA

Corresponding Author:

Timothy J. Gilfoyle, Department of History, Loyola University Chicago, 1032 W. Sheridan Road, Chicago, IL 60660, USA.

Email: tgilfoy@luc.edu 
(1961), Mumford offered one of the initial global histories of urbanization. The rise of the city was a development so profound, he argued, that it emancipated humankind from the primitive, irrational life of rural society. Urban structures, in Mumford's mind, were the final product of science and technology, the culmination of the increasing value attached to rational thought. Tracing large shifts in economic organization, alterations in city geography and the built environment, and the transformation of social life, Mumford's meta-narrative thematically linked culture, politics, and technology within a comprehensive account of Western urbanization. ${ }^{7}$

Katz insightfully points out that participants in the Yale conference intended to move beyond the paradigms of Schlesinger and Mumford. Many did so by adopting methodologies that emphasized the city as a site with emblematic social processes. Simultaneous and equally important was the previous and concurrent work of Sam Bass Warner Jr. Streetcar Suburbs (1962) — considered by many to be the groundbreaking text that stimulated the explosion of suburban studies in the next half century - employed Boston as a case study representative of the larger national process of suburbanization. Then in The Private City (1968) and The Urban Wilderness (1972), Warner used specific spatial sites-Philadelphia in three specific chronological periods in the former and Philadelphia, New York, and Los Angeles in the latter - to demonstrate a distinctive American urbanization that evolved out of an ideology that valorized market development, which he labeled "privatism." Warner focused on the specific structures and creations of urban communities. But in describing American urbanization as the fusion of thousands of individual, money-making citizens and autonomous, accumulating enterprises, he placed cities in the center of the history of American capitalism. ${ }^{8}$

Warner's scaffolding paradigm, the Yale conference, and Theodore Hershberg's Philadelphia represented and generated influential spatial examinations of cities. Equally significant, they stimulated case study approaches. For this generation of historians, the physical city served as a case study for larger social processes and transformations. Cases studies may have tumbled into disfavor among social scientists as Katz points out, but for urban historians they became de rigueur. The examples he cites by Max Page, Margaret Pugh O'Mara, Domenic Vitiello, and Alison Isenberg exemplify the use of a metropolitan area (New York, Silicon Valley, and Philadelphia, respectively) or an urban spatial form (downtowns) as case studies illustrating larger urban processes. ${ }^{9}$ Similarly, the influence of Jane Jacobs generated "thick descriptions" of urban neighborhoods and detailed examinations of urban political economies, replacing Mumford's "textile" and "Coketown" paradigms of nineteenth- and twentieth-century cities after $1970 . .^{10}$

Katz identifies the "urban crisis" as an influential event not only in the United States but in the way historians thereafter wrote about cities. Perhaps the most influential work on the urban crisis, however, was Arnold Hirsch's Making the Second Ghetto. Hirsch creatively integrated concepts of race, space, and place, demonstrating how socially constructed ideas of race influenced the spatial forms of segregation in specific neighborhoods in a specific city. Between 1940 and 1970, a state-sanctioned "second ghetto" with a distinctive form of spatial segregation emerged, supported by white, Euro-American "ethnics" defending their "homeowner rights" and downtown elites striving to preserve commercial real estate values. This pattern of racial exclusion was, according to Hirsch, "so pervasive, so deep, that it virtually constituted a new form of de jure segregation." 11

Making the Second Ghetto did more than challenge prevailing interpretations of residential segregation and racial exclusion. First, Hirsch's study generated a school of "second ghetto" interpretations. ${ }^{12}$ Second, Making the Second Ghetto stimulated another group of urbanists to challenge prevailing interpretations that located the breakdown of the New Deal coalition, the "urban crisis," and the rise of "Reagan Democrats" with Lyndon Johnson's War on Poverty after 1965. ${ }^{13}$ These and other historians identified the origins of these events in the decade after World War II. Finally, Hirsch previewed later scholarship on the social and linguistic construction of 
race, particularly the concepts of "whiteness" and the "merging of "ethnics" as analytical tools for understanding racial segregation. ${ }^{14}$

Katz paints a broad landscape in his overview. In so doing, however, he creates a binary evolution of urban history that sometimes obscures and oversimplifies. At least five trends in urban history complicate Katz's paradigm. First, studies of cities as places shaped by urban forms never supplanted earlier methods of studying cities as sites of social processes and institutions. These conceptualizations have existed side by side for the past half century. One example is the considerable literature that examines the social processes associated with disorder and "deviancy," which expands not only earlier definitions of the underworld, policing, and informal economies but moves alternative subcultures from the marginal to center-stage narratives in urban history. ${ }^{15}$ Similarly, recent studies in comparative urbanization — some by Katz's very own students — use urban renewal, segregation, ethnicity, and other urban "products" to attend equally to the social processes and institutions (the city as site) found in a specific urban place or form (usually a neighborhood, if not a specific city). ${ }^{16}$

Second, Katz asserts that "little work examines how networks of urban cultural institutions have been buffeted by and responded to urban transformation." Yet a considerable literature does just this. Examinations of women's organizations, African American cultural institutions, Jewish synagogues, Progressive reform, and social work institutions emphasize the many and multiple responses to the transformative processes of domestic migration, foreign immigration, and urbanization. ${ }^{17}$ Other studies adopting anthropological and ethnographic methodologies treat culture broadly, demonstrating how rapid urbanization created new communities, transformed their neighborhood institutions, upset residential spatial patterns, and even restructured sexual intimacy. More significantly, they make visible social groups largely invisible in the historical literature prior to $1960 .{ }^{18}$

Recent studies of urban religion, in particular, reveal how urban spaces and places not only affected religious groups but how those groups transformed city neighborhoods. The appropriation of urban space for particular devotional rituals was sometimes the external manifestation of a distinctive inner religiosity. For example, John McGreevy, Ellen Skerrett, Eileen McMahon, Gerald Gamm, and others emphasize how twentieth-century American urban Catholics adopted a sacralized attachment to residential property and the urban neighborhood, thereby identifying a resilient relationship between urban space and religious worship. ${ }^{19}$ Robert Orsi demonstrates how a street feste in New York and a religious shrine in Chicago became "in-between" places, "placeless sites," and devotional spaces that did not require a physical journey in the minds of the devout. Thomas Tweed shows how another shrine in Miami became a "translocational place," transmitting lore not only about the past but also the future. In these spaces, the religious or symbolic power of the place becomes so powerful that the pilgrimage location transcends other forms of interaction (letters, petitions, classified advertisements). More importantly, city streets and urban places serve as sources of religious vitality"existential multiplicity" in Orsi's words - and thereby become spaces facilitating religious creativity, innovation, and experimentation (think Jane Jacobs), not breakdown and decline (as imagined by the Chicago school sociologists). ${ }^{20}$ And the appropriation of space for religious purposes was not unique to Catholics. Diane Winston and Kyle Roberts demonstrate how different evangelical groups adopted missionary strategies shaped by specific streets in New York, resulting in a sacralization of secular space or "sanctification of the commonplace."21 These historians of urban religion, by scrutinizing the devotional and cultural practices that make territorial claims on shrines, churches, streets, and neighborhoods, have compelled urbanists to reconceptualize space and place.

Third, the most innovative work in architectural history and landscape studies frequently combine methods focusing on a city as site and place, weaving social and cultural history into 
the evolution of a built environment. The vast literature on urban parks best exemplifies this trend. ${ }^{22}$ Equally important, however, recent historians employ the Brooklyn Bridge in New York, the Prudential Center in Boston, and the Golden Gate Bridge in San Francisco to demonstrate the interrelated relationships among architectural structures, urban politics, and social institutions to illuminate broader historical and cultural themes. ${ }^{23}$ The multiple-volume examinations of New York and Chicago architecture by Robert A. M. Stern and his coauthors and John Zukowsky, respectively, are among the most encyclopedic since I. N. Phelps Stokes's opus on Manhattan. ${ }^{24}$ Other studies, inspired by the work of Robert Venturi, Denise Scott Brown, and Steven Izenour, focus on "ordinary" landscapes - the department store, the shopping mall, the gas station, the supermarket, the drive-in, the bungalow, the theme park, the street - and apply questions and methods associated with social history to the evolution of the built environment. ${ }^{25}$ Finally, the "Los Angeles school" of urbanism with its distinct emphasis on geography, class, and metropolitan urbanization exemplifies still another series of debates on urban forms. ${ }^{26}$

Fourth, numerous and significant urban histories do not neatly fall into this binary divisions of site or place. This is particularly true in urban environmental history, infrastructure history, and the impact of technology on cities. Some works in these fields adhere to Katz's concept of spatial place as a bounded entity, including Harold Platt on Chicago, Andrew Hurley on St. Louis and Gary, and Greg Hise and William Deverell on Los Angeles. ${ }^{27}$ More often they do not. William Cronon's Nature's Metropolis, ostensibly a work about Chicago, is equally an examination of the nineteenth-century environmental economy of the "greater West" and reflective of regional approaches to urban or metropolitan history. ${ }^{28}$ Others, notably Joel Tarr and Clay McShane, reveal how a particular technology or natural entity - the car, the bike, the horse, the rivertransformed urban life and beyond. ${ }^{29}$

Fifth, the bulk of Katz's examples focuses on the twentieth century, especially in the postwar period. This attention is deserved, especially since the most important work examines the growing importance of the "suburban" form. But this vast literature now goes beyond questions focused on place, space, and form to examine equally complex subjects of environmentalism, race, gender, religion, and class. ${ }^{30}$ Increasingly, the home, the built residence, or the housing project has served as the physical vehicle and intersection to examine these issues. ${ }^{31}$

Finally, "traditional" urban history never vanished. Exemplified by urban biography on one hand and urban political history on the other, a robust literature of individual city histories and political biographies has thrived. Edwin Burrows and Mike Wallace's Gotham: A History of New York City to 1898 (1999) represents the most popular urban biography of the past half century because of its successful synthesizing and narration. But frequently this literature eschews the theoretical paradigms associated with the city as site or city as place. ${ }^{32}$ Related to this, urban political biography remains a popular genre. Although published more than 35 years ago, Robert Caro's The Power Broker: Robert Moses and the Fall of New York (1974) remains influential and the subject of seemingly constant revision. ${ }^{33}$

These disagreements, however, should not diminish the importance of Katz's arguments. His evolutionary conceptualizations of the city as site and place represent how one generation of urban historians and social scientists made sense of the chaotic metropolis. The impact extends beyond the academy; Americans think differently about their cities and suburbs today. In 1970, Richard Wade lamented the dearth of research on American cities. ${ }^{34} \mathrm{Few}$ make such claims today. Michael Katz is one reason why.

\section{Declaration of Conflicting Interests}

The author declared no potential conflicts of interest with respect to the research, authorship, and/or publication of this article. 


\section{Funding}

The author received no financial support for the research, authorship, and/or publication of this article.

\section{Notes}

1. On education, see Michael B. Katz, The Irony of Early School Reform: Educational Innovation in MidNineteenth Century Massachusetts (Cambridge, MA: Harvard University Press, 1968); Katz, Class, Bureaucracy, and Schools: The Illusion of Educational Change in America (New York: Praeger, 1971); Katz, Reconstructing American Education (Cambridge, MA: Harvard University Press, 1987). On geographic mobility and transiency, see Katz, The People of Hamilton, Canada West: Family and Class in a Mid-Nineteenth-Century City (Cambridge, MA: Harvard University Press, 1975). On the persistence of urban poverty, see Katz, ed., The "Underclass" Debate: Views from History (Princeton: Princeton University Press, 1993); Katz, In the Shadow of the Poorhouse: A Social History of Welfare in America (New York: Basic Books, 1996); Katz, The Undeserving Poor: America's Enduring Confrontation with Poverty (New York: Pantheon, 1989). On historical sociology, see Katz and Thomas Sugrue, eds., W.E.B. DuBois, Race, and the City: The Philadelphia Negro and Its Legacy (Philadelphia: University of Pennsylvania Press, 1998). On urban disorder, see Katz, Why Don't American Cities Burn? (Philadelphia: University of Pennsylvania Press, 2012). On the multiple and profound intersections of these subjects, see Katz, Improving Poor People: The Welfare State, the "Underclass," and Urban Schools as History (Princeton: Princeton University Press, 1995); Katz and Mark J. Stern, One Nation Divisible: What America Was and What It Is Becoming (New York: Russell Sage Foundation, 2006).

2. Stephan Thernstrom and Richard Sennett, eds., Nineteenth-Century Cities: Essays in the New Urban History (New Haven, CT: Yale University Press, 1969); Theodore Hershberg, ed., Philadelphia: Work, Space, Family, and Group Experience in the Nineteenth Century (New York: Oxford University Press, 1981).

3. I have written about this in greater depth in Timothy J. Gilfoyle, "American Urban Histories," in A Century of American Historiography, ed. James M. Banner Jr. (Boston: Bedford/St. Martin's, 2009), 156-69; Gilfoyle, "Urbanization," in William Barney, ed., A Companion to 19th-Century America (Oxford, England: Blackwell, 2001), 152-63; Gilfoyle, "White Cities, Linguistic Turns, and Disneylands: Recent Paradigms in Urban History," Reviews in American History 26, no. 1 (March 1998), 175-204; and Louis P. Masur, ed., The Challenge of American History (Baltimore: Johns Hopkins University Press, 1999), 175-204; reprinted as "The New Paradigms of Urban History," in Major Problems in American Urban and Suburban History, 2nd edition, ed. Howard Chudacoff and Peter C. Baldwin (Boston: Houghton Mifflin, 2005), 19-34.

4. Arthur M. Schlesinger, Sr., The Rise of the City, 1878-1898 (New York: Macmillan, 1933).

5. Robert Park, Ernest W. Burgess, Roderick D. McKenzie, and Louis Wirth, The City (Chicago: University of Chicago Press, 1925), 219.

6. Richard C. Wade, The Urban Frontier: Pioneer Life in Early Pittsburgh, Cincinnati, Lexington, Louisville, and St. Louis (Cambridge: Harvard University Press, 1959); John C. Reps, The Making of Urban America: A History of City Planning in the United States (Princeton: Princeton University Press, 1965).

7. Lewis Mumford, The Culture of Cities (New York: Harcourt, Brace, 1938); Mumford, The City in History: Its Origins, Its Transformations, Its Prospects (New York: Harcourt, Brace, 1961).

8. Sam Bass Warner, Jr., Streetcar Suburbs: The Process of Growth in Boston, 1870-1900 (Cambridge: Harvard University Press, 1962); Warner, The Private City: Philadelphia in Three Periods of Its Growth (Philadelphia: University of Pennsylvania Press, 1968); Warner, The Urban Wilderness: A History of the American City (New York: Harper and Row, 1972).

9. Max Page, The Creative Destruction of Manhattan, 1900-1940 (Chicago: University of Chicago Press, 2000); Margaret Pugh O'Mara, Cities of Knowledge: Cold War Science and the Search for the Next Silicon Valley (Princeton: Princeton University Press, 2004); Domenic Vitiello, Engineering Philadelphia: The Sellers Family and the Industrial Metropolis (Ithaca, NY: Cornell University Press, 2013); Alison Isenberg, Downtown America: A History of the Place and the People Who Made It (Chicago: University of Chicago Press, 2005). 
10. Jane Jacobs, The Death and Life of Great American Cities (New York: Vintage, 1961); Mumford, The City in History, 446-81. In the past quarter century, this literature is vast. On neighborhoods, see James R. Grossman, Land of Hope: Chicago, Black Southerners, and the Great Migration (Chicago: University of Chicago Press, 1989); Lizabeth Cohen, Making a New Deal: Industrial Workers in Chicago, 1919-1939 (New York: Cambridge University Press, 1990); Nicholas Lemann, The Promised Land: The Great Black Migration and How It Changed America (New York: Knopf, 1991); Roger Lane, William Dorsey's Philadelphia and Ours: On the Past and Future of the Black City in America (New York: Oxford University Press, 1991); Cheryl Lynn Greenberg, Or Does It Explode?: Black Harlem in the Great Depression (New York: Oxford University Press, 1991); Alexander von Hoffman, Local Attachments: The Making of an American Urban Neighborhood (Baltimore: Johns Hopkins University Press, 1995); Robin F. Bachin, Building the South Side: Urban Space and Civic Culture in Chicago, 1890-1919 (Chicago: University of Chicago Press, 2004); Tyler Anbinder, Five Points (New York: Free Press, 2001); Wendell Pritchett, Brownsville, Brooklyn: Blacks, Jews, and the Changing Face of the Ghetto (Chicago: University of Chicago Press, 2002); Amanda I. Seligman, Block by Block: Neighborhoods and Public Policy on Chicago's West Side (Chicago: University of Chicago Press, 2005); Colin Gordon, Mapping Decline: St. Louis and the Fate of the American City (Philadelphia: University of Pennsylvania Press, 2008); Beryl Satter, Family Properties: Race, Real Estate, and the Exploitation of Black Urban America (New York: Metropolitan Books, 2009); Richard Campanella, Bourbon Street: A History (Baton Rouge: Louisiana State University Press, 2014); Ocean Howell, City within a City: Planning and Ethnicity in San Francisco's Mission District (Chicago: University of Chicago Press, forthcoming). On urban political economies broadly defined, see Thomas M. Doerflinger, A Vigorous Spirit of Enterprise: Merchants and Economic Development in Revolutionary Philadelphia (Chapel Hill: University of North Carolina Press, 1984); Sean Wilentz, Chants Democratic: New York City and the Rise of the American Working Class, 1788-1850 (New York: Oxford University Press, 1984); John Cumbler, A Social History of Economic Decline: Business, Politics, and Work in Trenton (New Brunswick: Rutgers University Press, 1989); Stuart M. Blumin, The Emergence of the Middle Class: Social Experience in the American City, 1760-1900 (New York: Cambridge University Press, 1989); Richard Schneirov, Labor and Urban Politics: Class Conflict and the Origins of Modern Liberalism in Chicago (Urbana: University of Illinois Press, 1998); Robert Lewis, Manufacturing Montreal: The Making of an Industrial Landscape, 1850-1930 (Baltimore: Johns Hopkins University Press, 2000); Lewis, Chicago Made: Factory Networks in the Industrial Metropolis (Chicago: University of Chicago Press, 2008); Andrew Wender Cohen, The Racketeer's Progress: Chicago and the Struggle for the Modern American Economy, 1900-1940 (New York: Cambridge University Press, 2004); Guian McKee, The Problem of Jobs: Liberalism, Race, and Deindustrialization in Philadelphia (Chicago: University of Chicago Press, 2008); Monica Perales, Smeltertown: Making and Remembering a Southwest Border Community (Chapel Hill: University of North Carolina Press, 2010); Domenic Vitiello, The Philadelphia Stock Exchange and the City It Made (Philadelphia: University of Pennsylvania Press, 2010); Eric J. Moser, Hinterland Dreams: The Political Economy of a Midwestern City (Philadelphia: University of Pennsylvania Press, 2010); Elizabeth Tandy Shermer, Sunbelt Capitalism: Phoenix and the Transformation of American Politics (Philadelphia: University of Pennsylvania Press, 2013).

11. Arnold Hirsch, Making the Second Ghetto: Race and Housing in Chicago, 1940-1960 (New York: Cambridge University Press, 1983; reissued Chicago: University of Chicago Press, 1998), esp. 254-55.

12. Raymond A. Mohl, "Making the Second Ghetto in Metropolitan Miami, 1940-1960," Journal of Urban History 21 (March 1995): 410-13; Raymond A. Mohl, "The Second Ghetto and the "Infiltration Theory' in Urban Real Estate 1940-1960," in Urban Planning and the African American Community: In the Shadows, ed. June Manning Thomas and Marsha Ritzdorf (Thousand Oaks, CA: Sage, 1997), 58-74; the articles by Raymond Mohl, Roger Biles, Wendy Plotkin, Amanda Irene Seligman, and D. Bradford Hunt in the Journal of the Illinois State Historical Society 94 (2001): 8-123; and articles by Ronald Bayor, Raymond A. Mohl, Carl H. Nightingale, Amanda Irene Seligman, Thomas J. Sugrue, and Heather Ann Thompson in "Special Issue: Urban History, Arnold Hirsch, and the Second Ghetto Thesis," Journal of Urban History 29 (2003): 238-309.

13. Thomas J. Sugrue, The Origins of the Urban Crisis: Race and Inequality in Postwar Detroit (Princeton: Princeton University Press, 1996); Sugrue, Sweet Land of Liberty: The Forgotten Struggle 
for Civil Rights in the North (New York: Random House, 2008); Douglas Massey and Nancy A. Denton, American Apartheid: Segregation and the Making of the Underclass (Cambridge: Harvard University Press, 1993); Pritchett, Brownsville, Brooklyn; Robert O. Self, American Babylon: Race and the Struggle for Postwar Oakland (Princeton: Princeton University Press, 2003); Jefferson Cowie and Joseph Heathcott, eds., Beyond the Ruins: The Meanings of Deindustrialization (Ithaca, NY: Cornell University Press, 2003); Bryant Simon, Boardwalk of Dreams: Atlantic City and the Fate of Urban America (New York: Oxford University Press, 2004); Howard Gillette, Jr., Camden after the Fall: Decline and Renewal in a Post-industrial City (Philadelphia: University of Pennsylvania Press, 2005); Shana Bernstein, Bridges of Reform: Interracial Civil Rights Activism in Twentieth-Century Los Angeles (New York: Oxford University Press, 2011). For works locating the breakdown of the New Deal coalition with Lyndon Johnson's War on Poverty after 1965, see Jonathan Reider, Canarsie: The Jews and Italians of Brooklyn against Liberalism (Cambridge: Harvard University Press, 1985); Allen Matusow, The Unraveling of America: A History of Liberalism in the 1960s (New York: Harper \& Row, 1984); and Thomas Byrne Edsall and Mary D. Edsall, Chain Reaction: The Impact of Race, Rights and Taxes on American Politics (New York: Norton, 1991).

14. On Hirsch being among the earliest to use the term "whiteness," see Hirsch, Making the Second Ghetto, 186; and Sugrue, "Revisiting the Second Ghetto," 283-86. Some of the best and most provocative assessments of whiteness studies fail to acknowledge Hirsch. See Eric Arnesen, "Whiteness and the Historians' Imagination," International Labor and Working-Class History 60 (2001): 3-32; and Peter Kolchin, "Whiteness Studies: The New History of Race in America," Journal of American History 89 (2002): 154-73. On the social construction of whiteness, see David R. Roediger, The Wages of Whiteness: Race and the Making of the American Working Class (New York: Verso, 1991); Alexander Saxton, The Rise and Fall of the White Republic: Class Politics and Mass Culture in NineteenthCentury America (New York: Verso, 1990).

15. Carl Smith, Urban Disorder and the Shape of Belief in the Great Chicago Fire, the Haymarket Bomb, and the Model Town of Pullman (Chicago: University of Chicago Press, 1994); Madelon Powers, Faces along the Bar: Lore and Order in the Workingman's Saloon, 1870-1920 (Chicago: University of Chicago Press, 1998); Peter C. Baldwin, Domesticating the Street: The Reform of Public Space in Hartford, 1850-1930 (Columbus: Ohio State University Press, 1999); Eric Schneider, Vampires, Dragons and Egyptian Kings: Youth Gangs in Postwar New York (Princeton: Princeton University Press, 1999); Eric Monkkonen, Murder in New York City (Berkeley: University of California Press, 2001); Edward J. Escobar, "Bloody Christmas and the Irony of Police Professionalism: The Los Angeles Police Department, Mexican Americans, and Police Reform in the 1950s," Pacific Historical Review 72 (2003): 171-99; Timothy J. Gilfoyle, A Pickpocket's Tale: The Underworld of NineteenthCentury New York (New York: Norton, 2006); Eric C. Schneider, Smack: Heroin and the American City (Philadelphia: University of Pennsylvania Press, 2008); Andrew Diamond, Mean Streets: Chicago Youths and the Everyday Struggle for Empowerment in the Multiracial City, 1908-1969 (Berkeley: University of California Press, 2009); Jennifer Fronc, New York Undercover: Private Surveillance in the Progressive Era (Chicago: University of Chicago Press, 2009); Lisa Keller, Triumph of Order: Democracy \& Public Space in New York and London (New York: Columbia University Press, 2009); Heather Ann Thompson, "Why Mass Incarceration Matters: Rethinking Crisis, Decline, and Transformation in Postwar American History," Journal of American History 97 (2010); Amanda I. Seligman, "'But Burn-No': The Rest of the Crowd in Three Civil Disorders in 1960s Chicago," Journal of Urban History (2011): 230-55; Christopher Lowen Agee, The Streets of San Francisco: Policing and the Creation of Cosmopolitan Liberal Politics, 1950-1972 (Chicago: University of Chicago Press, 2014). Also see the works cited in note 20 below.

16. Harold Platt, Shock Cities: The Environmental Transformation and Reform of Manchester and Chicago (Chicago: University of Chicago Press, 2005); Jordan Stanger-Ross, Staying Italian: Urban Change and Ethnic Life in Postwar Toronto and Philadelphia (Chicago: University of Chicago Press, 2010); Jerome I. Hodos, Second Cities: Globalization and Local Politics in Manchester and Philadelphia (Philadelphia: Temple University Press, 2011); Christopher Klemek, The Transatlantic Collapse of Urban Renewal: Postwar Urbanism from New York to Berlin (Chicago: University of Chicago Press, 2011); Carl H. Nightingale, Segregation: A Global History of Divided Cities (Chicago: University of Chicago Press, 2012). 
17. Sarah Deutsch, Women and the City: Gender, Space and Power in Boston, 1870-1940 (New York: Oxford University Press, 2000); Maureen A. Flanagan, Seeing with Their Hearts: Chicago Women and the Vision of the Good City, 1871-1933 (Princeton: Princeton University Press, 2002); Michael Willrich, City of Courts: Socializing Justice in Progressive Era Chicago (New York: Cambridge University Press, 2003); David Tanenhaus, Juvenile Justice in the Making (New York: Oxford University Press, 2004); Adam Green, Selling the Race: Culture, Community, and Black Chicago, 1940-1955 (Chicago: University of Chicago Press, 2006); Cheryl Hicks, Talk With You Like a Woman: Urban Reform, Criminal Justice and African American Women in New York, 1890-1945 (Chapel Hill: University of North Carolina Press, 2010); Mark Peel, Miss Cutler and the Case of the Resurrected Horse: Social Work and the Story of Poverty in America, Australia, and Britain (Chicago: University of Chicago Press, 2011); Tobias Brinkman, Sundays at Sinai: A Jewish Congregation in Chicago (Chicago: University of Chicago Press, 2012); Jeffrey Helgeson, Crucibles of Black Empowerment: Chicago's Neighborhood Politics from the New Deal to Harold Washington (Chicago: University of Chicago Press, 2014).

18. Kathy Peiss, Cheap Amusements: Working Women and Leisure in Turn-of-the-Century New York (Philadelphia: Temple University Press, 1986); Christine Stansell, City of Women: Sex and Class in New York, 1790-1860 (New York: Knopf, 1986); Joanne Meyerowitz, Women Adrift: Independent Wage Earners in Chicago, 1880-1930 (Chicago: University of Chicago Press, 1988); Elizabeth Lapovsky Kennedy and Madeline D. Davis, Boots of Leather, Slippers of Gold: The History of a Lesbian Community (New York: Routledge, 1993); David Nasaw, Going Out: The Rise and Fall of Public Amusements (New York; Basic Books, 2003); George Chauncey, Gay New York: Gender, Urban Culture, and the Making of the Gay Male World (New York: Basic Books, 1994); Lewis A. Erenberg, Swinging' the Dream: Big Band Jazz and the Rebirth of American Culture (Chicago: University of Chicago Press, 1998); Patricia Cline Cohen, The Murder of Helen Jewett (New York: Knopf, 1998); Cohen, Timothy J. Gilfoyle, and Helen Lefkowitz Horowitz, The Flash Press: Sporting Male Weeklies in the 1840s (Chicago: University of Chicago Press, 2008); Timothy J. Gilfoyle, City of Eros: New York City, Prostitution, and the Commercialization of Sex, 1790-1920 (New York: Norton, 1992); Moshe Shokeid, A Gay Synagogue in New York (New York: Columbia University Press, 1995); Elizabeth Clement, Love for Sale: Courting, Treating, and Prostitution in New York City, 1900-1945 (Chapel Hill: University of North Carolina Press, 2006); Chad Heap, Slumming: Sexual and Racial Encounters in American Nightlife, 1885-1940 (Chicago: University of Chicago Press, 2009); Cynthia M. Blair, I've Got to Make my Livin': Black Women's Sex Work in Turn-of-the-Century Chicago (Chicago: University of Chicago Press, 2010); Baldwin, In the Watches of the Night; Cindy R. Lobel, Urban Appetites: Food and Culture in Nineteenth-Century New York (Chicago: University of Chicago Press, 2014). Also see the works cited in note 15 above.

19. Ellen Skerrett, The Irish Parish in Chicago, 1880-1930 (Notre Dame: University of Notre Dame, 1981); Skerrett, Edward R. Kantowicz, and Steven M. Avella, Catholicism, Chicago Style (Chicago: Loyola University Press, 1993); Skerrett, "The Irish of Chicago's Hull-House," in Perspectives on the Irish Diaspora, ed. Charles Fanning (Carbondale: Southern Illinois Press, 2000), 189-222; Eileen McMahon, Which Parish Are You From? A Chicago Irish Community and Race Relations (Lexington: University Press of Kentucky, 1995); John T. McGreevy, Parish Boundaries: The Catholic Encounter with Race in the Twentieth-Century Urban North (Chicago: University of Chicago Press, 1996); Gerald Gamm, Urban Exodus: Why the Jews Left Boston and the Catholics Stayed (Cambridge: Harvard University Press, 1999). Also see Maureen Fitzgerald, Habits of Compassion: Irish Catholic Nuns and the Origins of New York's Welfare System, 1830-1920 (Urbana: University of Illinois Press, 2006); Suellen Hoy, Good Hearts: Catholic Sisters in Chicago's Past (Urbana: University of Illinois, 2006); Timothy Neary, Crossing Parish Boundaries: African Americans and Catholic Interracialism in Chicago, 1914-1954 (Chicago: University of Chicago Press, forthcoming).

20. Robert A. Orsi, The Madonna of 115th Street: Faith and Community in Italian Harlem, 1880-1950 (New Haven, CT: Yale University Press, 1985); Orsi, Thank You, St. Jude: Women's Devotion to the Patron Saint of Hopeless Causes (New Haven, CT: Yale University Press, 1996), 141 (placeless site), 200-206 (in-betweenness); Orsi, "The Center Out There, In Here, and Everywhere Else: The Nature of Pilgrimage to the Shrine of St. Jude, 1929-1965," Journal of Social History 25 (1991): 213-32; Orsi, "The Religious Boundaries of an Inbetween People: Street Feste and the Problem of the Dark-Skinned 
Other in Italian Harlem, 1920-1990," American Quarterly 44 (1992): 313-41, reprinted in Orsi, ed., Gods of the City: Religion and the American Urban Landscape (Bloomington: Indiana University Press, 1999), 257-88; Thomas A. Tweed, Our Lady of the Exile: Diasporic Religion at a Cuban Catholic Shrine in Miami (New York: Oxford University Press, 1997); Orsi, "Introduction: Crossing the City Line"; Tweed, "Diasporic Nationalism and Urban Landscape: Cuban Immigrants at a Catholic Shrine in Miami"; David H. Brown, "Altared Spaces: Afro-Cuban Religions and the Urban Landscape in Cuba and the United States," all in Orsi, ed., Gods of the City, 41-49, 57-59, 58 (existential multiplicity), 131-230; Alyshia Gálvez, Guadalupe in New York: Devotion and Struggle for Citizenship Rights among Mexican Immigrants (New York: New York University Press, 2010).

21. Diane Winston, Red-Hot and Righteous: The Urban Religion of the Salvation Army (Cambridge, MA: Harvard University Press, 1999); Winston, "The Cathedral of the Open Air": The Salvation Army's Sacralization of Secular Space, New York City, 1880-1910," in Orsi, ed., Gods of the City, 367-92; Kyle Roberts, Evangelical Gotham: Religion and the Making of New York City, 1783-1860 (Chicago: University of Chicago Press, forthcoming).

22. David Schuyler, The New Urban Landscape: The Redefinition of Urban Form in Nineteenth-Century America (Baltimore: Johns Hopkins University Press, 1986); Schuyler, Apostle of Taste: Andrew Jackson Downing, 1815-1852 (Baltimore: Johns Hopkins University Press, 1996); David C. Sloane, The Last Great Necessity: Cemeteries in American History (Baltimore: Johns Hopkins University Press, 1991); Elizabeth Blackmar and Roy Rosenzweig, The Park and the People: A History of Central Park (Ithaca, NY: Cornell University Press, 1992); Dennis Domer, ed., Alfred Caldwell: The Life and Work of a Prairie School Landscape Architect (Baltimore: Johns Hopkins University Press, 1997); Francis R. Kowsky, Country, Park, and City: The Architecture and Life of Calvert Vaux (New York: Oxford University Press, 1997); Judith K. Major, To Live in the New World: A.J. Downing and American Landscape Gardening (Cambridge, MA: MIT Press, 1997); Witold Rybczynski, A Clearing in the Distance: Frederick Law Olmsted and America in the Nineteenth Century (New York: Scribner, 1999).

23. David McCullough, The Great Bridge: The Epic Story of the Building of the Brooklyn Bridge (New York: Simon and Schuster, 1972); Alan Trachtenberg, Brooklyn Bridge: Fact and Symbol (Chicago: University of Chicago Press, 1979); Elihu Rubin, Insuring the City: The Prudential Center and the Postwar Urban Landscape (New Haven, CT: Yale University Press, 2012); Louise Nelson Dyble, Paying the Toll: Local Power, Regional Politics and the Golden Gate Bridge (Philadelphia: University of Pennsylvania Press, 2009). Also see Carol Willis, Form Follows Finance: Skyscrapers and Skylines in New York and Chicago (New York: Princeton Architectural Press, 1995); Sarah Bradford Landau and Carl W. Condit, Rise of the New York Skyscraper, 1865-1913 (New Haven, CT: Yale University Press, 1996); Robert Bruegmann, The Architects and the City: Holabird and Roche of Chicago, 1880-1918 (Chicago: The University of Chicago Press, 1997); Franz Schulze, Mies van der Rohe: A Critical Biography (Chicago: University of Chicago Press, 1985); John Tauranac, The Empire State Building: The Making of a Landmark (New York: Scribner, 1995); Larry R. Ford, Cities and Buildings: Skyscrapers, Skid Rows, and Suburbs (Baltimore: Johns Hopkins University Press, 1994); Olivier Zunz and David Ward, eds., The Landscape of Modernity (New York: Russell Sage Foundation, 1992); Bruce Radde, The Merritt Parkway (New Haven, CT: Yale University Press, 1993).

24. I. N. Phelps Stokes, The Iconography of Manhattan Island 1498-1909, 6 vols. (New York: Robert H. Dodd, 1915); Robert A. M. Stern, Pride of Place: Building the American Dream (Boston: Houghton Mifflin, 1986); Stern, Gregory Gilmartin, and John Massengale, New York 1900: Metropolitan Architecture and Urbanism, 1890-1915 (New York: Rizzoli, 1983); Stern, Gilmartin, and Thomas Mellins, New York 1930: Architecture and Urbanism between the Two World Wars (New York: Rizzoli, 1987); Stern, Mellins, David Fishman, New York 1960: Architecture and Urbanism Between the Second World War and the Bicentennial (New York: Monacelli, 1995); John Zukowsky, ed., Chicago and New York: Architectural Interactions (Chicago: Art Institute of Chicago, 1984); Zukowsky, ed., Chicago Architecture, 1872-1922: Birth of a Metropolis (Chicago: Art Institute of Chicago, 1987); Zukowsky, ed., Chicago Architecture, 1923-1993: Reconfiguration of an American Metropolis (Chicago: Art Institute of Chicago, 1993).

25. Robert Venturi, Denise Scott Brown, and Steven Izenour, Learning from Las Vegas: The Forgotten Symbolism of Architectural Form (Cambridge: MIT Press, 1972, revised 1994); Sharon Zukin, 
Landscapes of Power: From Detroit to Disneyland (Berkeley: University of California Press, 1991); Daniel Bluestone, Constructing Chicago (New Haven, CT: Yale University Press, 1991); William R. Leach, Land of Desire: Merchants, Power and the Rise of New American Culture (New York: Random House, 1993); John A. Jakle and Keith A. Sculle, The Gas Station in America (Baltimore: Johns Hopkins University Press, 1994); Jan Cigliano and Sarah Bradford Landau, eds., The Grand American Avenue 1850-1920 (San Francisco: Pomegranate Artbooks, 1994); Allan B. Jacobs, Great Streets (Cambridge: MIT Press, 1995); Kenneth T. Jackson, "All the World's a Mall: Reflections on the Social and Economic Consequences of the American Shopping Center," American Historical Review 101 (1996): 1050-1121; Lizabeth Cohen, "From Town Center to Shopping Center: The Reconfiguration of Community Marketplaces in Postwar America," American Historical Review 101 (1996): 105081; Cohen, A Consumers' Republic: The Politics of Mass Consumption in Postwar America (New York: Knopf, 2003); Richard Longstreth, City Center to Regional Mall: Architecture, the Automobile, and Retailing in Los Angeles, 1920-1950 (Cambridge: MIT Press, 1997); Richard Longstreth, The Drive-In, the Supermarket, and the Transformation of Commercial Space in Los Angeles, 1914-1941 (Cambridge: MIT Press, 1999); Joseph Bigott, From Cottage to Bungalow: Houses and the Working Class in Metropolitan Chicago, 1869-1929 (Chicago: University of Chicago Press, 2001); Robert M. Fogelson, Downtown: Its Rise and Fall, 1880-1950 (New Haven, CT: Yale University Press, 2001); Keith Revell, Building Gotham: Civic Culture and Public Policy in New York City, 1898-1938 (Baltimore: Johns Hopkins University Press, 2002); M. Jeffrey Hardwick, Mall Maker: Victor Gruen, Architect of an American Dream (University of Pennsylvania Press, 2003); Carl Smith, The Plan of Chicago: Daniel Burnham and the Remaking of the American City (Chicago: University of Chicago Press, 2006).

26. Mike Davis, City of Quartz: Excavating the Future in Los Angeles (London: Verso, 1990); Davis, Ecology of Fear: Los Angeles and the Imagination of Disaster (New York: Metropolitan, 1998); Allen J. Scott and Edward W. Soja, eds., The City: Los Angeles and Urban Theory at the End of the Twentieth Century (Berkeley: University of California Press, 1996); David Harvey, The Condition of Postmodernity: An Enquiry into the Origins of Cultural Change (Oxford, England: Basil Blackwell, 1989); Michael Sorkin, ed., Variations on a Theme Park: Scenes from the New American City (New York: Pantheon, 1990); John Findlay, Magic Lands: Western Cityscapes and American Culture after 1940 (Berkeley: University of California Press, 1993); William F. Deverell, Railroad Crossing: Californians and the Railroad, 1850-1910 (Berkeley: University of California Press, 1994); Deverell, Whitewashed Adobe: The Rise of Los Angeles and the Remaking of Its Mexican Past (Berkeley: University of California Press, 2004); Michael J. Dear, H. Eric Schockman, Greg Hise, eds., Rethinking Los Angeles (Thousand Oaks, CA: Sage, 1996); Hise, Magnetic Los Angeles: Planning the TwentiethCentury Metropolis (Baltimore: Johns Hopkins University Press, 1997).

27. Harold L. Platt, The Electric City: Energy and the Growth of the Chicago Area, 1880-1930 (Chicago: University of Chicago Press, 1991); Andrew Hurley, Environmental Inequalities: Class, Race and Industrial Pollution in Gary, Indiana, 1945-1980 (Chapel Hill: University of North Carolina Press, 1995); Hurley, ed., Common Fields: An Environmental History of St. Louis (St. Louis: Missouri Historical Society Press, 1997); Greg Hise and William F. Deverell, Land of Sunshine: An Environmental History of Metropolitan Los Angeles (Pittsburgh: University of Pittsburgh Press, 2005).

28. William Cronon, Nature's Metropolis: Chicago and the Great West (New York: Norton, 1991); "William Cronon's Nature's Metropolis: A Symposium," Antipode 26 (1994): 113-76; Martin Melosi, The Sanitary City: Urban Infrastructure in America from Colonial Times to the Present. (Baltimore: Johns Hopkins University Press, 2000); Melosi, ed., Pollution and Reform in American Cities, 18701930 (Austin: University of Texas Press, 1980); Melosi, Garbage in the Cities: Refuse, Reform, and the Environment, 1880-1980 (College Station: Texas A\&M University Press, 1981); Joel Tarr, The Search for the Ultimate Sink: Urban Pollution in Historical Perspective (Akron, $\mathrm{OH}$ : University of Akron Press, 1996); Tarr, Infrastructure and Urban Growth in the Nineteenth Century (Chicago: Public Works Historical Society, 1985); Tarr and Gabriel Dupuy, eds., Technology and the Rise of the Networked City in Europe and America (Philadelphia: Temple University Press, 1988); Josef W. Konvitz, The Urban Millennium: The City Building Process from the Early Middle Ages to the Present (Carbondale: Southern Illinois University Press, 1985); Christine Meisner Rosen, The Limits of Power: Great Fires and the Process of City Growth in America (New York: Cambridge University Press, 1986); Rosen, 
"Infrastructural Improvement in Nineteenth-Century Cities: A Conceptual Framework and Cases," Journal of Urban History 12 (1986); Suellen Hoy, Chasing Dirt: The American Pursuit of Cleanliness (New York: Oxford University Press, 1995); Mark H. Rose, Cities of Light and Heat: Domesticating Gas and Electricity in Urban America (University Park: Pennsylvania State University Press, 1995); Sarah S. Elkind, Bay Cities and Water Pollution: The Battle for Resources in Boston and Oakland (Lawrence: University Press of Kansas, 1998); David Stradling, Smokestacks and Progressives: Environmentalists, Engineers, and Air Quality in America, 1881-1951 (Baltimore: Johns Hopkins University Press, 1999). On regional approaches, see Carl Abbott, The Metropolitan Frontier: Cities in the Modern American West (Tucson: University of Arizona Press, 1993); Abbott, "Dimensions of Regional Change in Washington, D.C.," American Historical Review 95 (1990): 1367-93; David Goldfield, Cottonfields and Skyscrapers: Southern City and Region, 1607-1980 (Baton Rouge: Louisiana State University Press, 1982); Goldfield, "The Urban South: A Regional Framework," American Historical Review 86 (1981): 1009-34; Goldfield, "The New Regionalism," Journal of Urban History 10 (1984): 171-86; Michelle Nickerson and Darren Dochuk, eds., Sunbelt Rising: The Politics of Space, Place, and Region (Philadelphia: University of Pennsylvania Press, 2011). For more on regionalism, southern urbanization, and sunbelt cities, see Gilfoyle, "White Cities," especially notes 48-53.

29. Clay McShane, Down the Asphalt Path: The Automobile and the American City (New York: Columbia University Press, 1994); McShane and Tarr, The Horse in the City: Living Machines in the Nineteenth Century (Baltimore: Johns Hopkins University Press, 2007); Mark Foster, From Streetcar to Superhighway: American City Planners and Urban Transportation, 1900-1940 (Philadelphia: Temple University Press, 1981); David St. Clair, The Motorization of American Cities (New York: Praeger, 1986); Glenn Yago, The Decline of Transit: Urban Transportation in German and U.S. Cities, 1900-1970 (New York: Cambridge University Press, 1984); Scott L. Bottles, Los Angeles and the Automobile: The Making of the Modern City (Berkeley: University of California Press, 1987); Martin Wachs and Margaret Crawford, eds., The Car and the City: The Automobile, the Built Environment, and Daily Urban Life (Ann Arbor: University of Michigan Press, 1991); Howard Rosen and Ann Durkin Keating, eds., Water and the City: The Next Century (Chicago: Public Works Association, 1991); Clifton Hood, 722 Miles: The Building of the Subways and How They Transformed New York (New York: Simon \& Schuster, 1994); Blake Gumprecht, The Los Angeles River: Its Life, Death, and Possible Rebirth (Baltimore: Johns Hopkins University Press, 1999); Kate Foss-Mollan, Hard Water: Politics and Water Supply in Milwaukee, 1870-1995 (West Lafayette, IN: Purdue University Press, 2000); Evan Friss, The Cycling City: Bicycles and Urban America in the 1890s (Chicago: University of Chicago Press, 2015).

30. Kenneth T. Jackson, Crabgrass Frontier: The Suburbanization of the United States (New York: Oxford University Press, 1985); Mark Baldassare, Trouble in Paradise: The Suburban Transformation of America (New York: Columbia University Press, 1986); Robert Fishman, Bourgeois Utopias: The Rise and Fall of Suburbia (New York: Basic Books, 1987); Joel Garreau, Edge City: Life on the New Frontier (New York: Doubleday, 1991); Jon Teaford, Post-Suburbia: Government and Politics in the Edge Cities (Baltimore: Johns Hopkins University Press, 1996); Thomas Hanchett, Sorting Out the New South City: Race, Class, and Urban Development in Charlotte, 1875-1975 (Chapel Hill: University of North Carolina Press, 1998); Richard Harris and Robert Lewis, "The Geography of North American Cities and Suburbs, 1900-1950," Journal of Urban History 27 (March 2001): 262-84; Becky Nicolaides, My Blue Heaven: Life and Politics in the Working-Class Suburbs of Los Angeles, 19201965 (Chicago: University of Chicago Press, 2001); Lisa McGirr, Suburban Warriors: The Origins of the New American Right (Princeton: Princeton University Press, 2001); Adam Rome, The Bulldozer in the Countryside: Suburban Sprawl and the Rise of American Environmentalism (New York: Cambridge University Press, 2001); Andrew Wiese, Places of Their Own: African American Suburbanization in the Twentieth Century (Chicago: University of Chicago Press, 2004); Robert Bruegmann, Sprawl: A Compact History (Chicago: University of Chicago Press, 2005); Ann Durkin Keating, Chicagoland: City and Suburbs in the Railroad Age (Chicago: University of Chicago Press, 2005); Kevin Kruse, White Flight: Atlanta and the Making of Modern Conservatism (Princeton: Princeton University Press, 2005); Kruse and Thomas Sugrue, eds., The New Suburban History (Chicago: University of Chicago Press, 2007); Matthew D. Lassiter, The Silent Majority: Suburban Politics in the Sunbelt 
South (Princeton: Princeton University Press, 2006); David M. P. Freund, Colored Property: State Policy and White Racial Politics in Suburban America (Chicago: University of Chicago Press, 2007); Michelle Nickerson, Mothers of Conservatism: Women and the Postwar Right (Princeton: Princeton University Press, 2012).

31. Gail Radford, Modern Housing for America: Policy Struggles in the New Deal Era (Chicago: University of Chicago Press, 1997); Bigott, From Cottage to Bungalow; Margaret Garb, City of American Dreams: A History of Home Ownership and Housing Reform in Chicago, 1871-1919 (Chicago: University of Chicago Press, 2005); D. Bradford Hunt, Blueprint for Disaster: The Unraveling of Chicago Public Housing (Chicago: University of Chicago Press, 2009); Charlotte Brooks, Alien Neighbors, Foreign Friends: Asian Americans, Housing, and the Transformation of Urban California (Chicago: University of Chicago Press, 2009); Lilia Fernandez, Brown in the Windy City: Mexicans and Puerto Ricans in Postwar Chicago (Chicago: University of Chicago Press, 2012); Richard Harris, Building a Market: The Rise of the Home Improvement Industry, 1914-1960 (Chicago: University of Chicago Press, 2012); Lawrence J. Vale, Purging the Poorest: Public Housing and the Design Politics of Twice-Cleared Communities (Chicago: University of Chicago Press, 2013); Robert M. Fogelson, The Great Rent Wars: New York, 1917-1929 (New Haven, CT: Yale University Press, 2013); Roberta Gold, When Tenants Claimed the City: The Struggle for Citizenship in New York City Housing (Urbana: University of Illinois Press, 2014).

32. Edwin G. Burrows and Mike Wallace, Gotham: A History of New York City to 1898 (New York: Oxford University Press, 1998); George J. Lankevich, American Metropolis: A History of New York City (New York: New York University Press, 1998); Allon Schoener, New York: An Illustrated History of the People (New York: Norton, 1998); Harold Mayer and Richard Wade, Chicago: Growth of a Metropolis (Chicago: University of Chicago Press, 1969); Donald L. Miller, City of the Century: The Epic of Chicago and the Making of America (New York: Simon and Schuster, 1996); Perry R. Duis, Challenging Chicago: Coping with Everyday Life, 1837-1920 (Urbana: University of Illinois Press, 1998); Dominic A. Pacyga, Chicago: A Biography (Chicago: University of Chicagp Press, 2009); Robert G. Spinney, City of Big Shoulders: A History of Chicago (Dekalb: Northern Illinois University Press, 2000); Thomas G. Alexander and James B. Allen, Mormons and Gentiles: A History of Salt Lake City (Boulder, CO: Pruett, 1984); Eugene P. Moehring, Resort City in the Sunbelt: Las Vegas, 1930-1970 (Reno: University of Nevada Press, 1989); Edward D. Beechert, Honolulu: Crossroads of the Pacific (Columbia: University of South Carolina Press, 1991); James B. Crooks, Jacksonville after the Fire, 1901-1919 (Gainesville: University Presses of Florida, 1991); G. Wesley Johnson, Jr., ed., Phoenix in the Twentieth Century: Essays in Community History (Norman: University of Oklahoma Press, 1993); Bradford Luckingham, The Urban Southwest: A Profile History of Albuquerque, El Paso, Phoenix, Tucson (El Paso: Texas Western Press, 1982); Luckingham, Phoenix: The History of a Southwestern Metropolis (Tucson: University of Arizona Press, 1989); Edward K. Spann, The New Metropolis: New York City, 1840-1857 (New York: Columbia University Press, 1981); Gary L. Browne, Baltimore in the Nation, 1789-1981 (Chapel Hill: University of North Carolina Press, 1990); Don Doyle, Nashville in the New South, 1880-1930 (Knoxville: University of Tennessee Press, 1983); Doyle, Nashville Since the 1920s (Knoxville: University of Tennessee Press, 1985); Michael J. McDonald and William Bruce Wheeler, Knoxville, Tennessee: Continuity and Change in an Appalachian City (Knoxville: University of Tennessee Press, 1983); Christopher Silver, Twentieth-Century Richmond: Planning, Politics and Race (Knoxville: University of Tennessee, 1984); Patricia E. Hill, Dallas: The Making of a Modern City (Austin: University of Texas Press, 1996).

33. Robert A. Caro, The Power Broker: Robert Moses and the Fall of New York (New York: Knopf, 1974); Thomas Kessner, Fiorello H. LaGuardia and the Making of Modern New York (New York: McGrawHill, 1989); Jon C. Teaford, The Rough Road to Renaissance: Urban Revitalization in America, 19401985 (Baltimore: Johns Hopkins University Press, 1990); Leonard Wallock, "The Myth of the Master Builder: Robert Moses, New York, and the Dynamics of Metropolitan Development Since World War II," Journal of Urban History 17 (1991): 339-62; Herbert J. Gans, People, Plans and Policies; Essays on Poverty, Racism, and Other National Urban Problems (New York: Columbia University Press and the Russell Sage Foundation, 1991); Joel Schwartz, The New York Approach: Robert Moses, Urban Liberals, and the Redevelopment of the Inner City (Columbus: Ohio State University Press, 1993); Kenneth T. Jackson and Hilary Ballon, eds., Robert Moses and the Modern City: The Transformation 
of New York (New York: Norton, 2007); Anthony Flint, Wrestling with Moses: How Jane Jacobs Took on New York's Master Builder and Transformed the American City (New York: Random House, 2009); Samuel Zipp, Manhattan Projects: The Rise and Fall of Urban Renewal in Cold War New York (New York: Oxford University Press, 2010). The literature on urban political biography is also vast. For recent examples, see Kessner, Fiorello H. LaGuardia; Adam Cohen and Elizabeth Taylor, American Pharaoh: Mayor Richard J. Daley—His Battle for Chicago and the Nation (Boston: Little, Brown, 2000); Wilbur C. Rich, David Dinkins and New York City Politics: Race, Images, and the Media (Albany: State University of New York Press, 2006); Wendell Pritchett, Robert Clifton Weaver and the American City: The Life and Times of an Urban Reformer (Chicago: University of Chicago Press, 2008); Christopher Manning, William L. Dawson and the Limits of Black Electoral Leadership (DeKalb, IL: Northern Illinois University Press, 2009); Keith Koeneman, First Son: The Biography of Richard M. Daley (Chicago: University of Chicago Press, 2013); Chris McNickle, The Power of the Mayor: David Dinkins, 1990-1993 (New Brunswick, NJ: Transaction Publishers, 2013); Joseph P. Viteritti, ed., Summer in the City: John Lindsay, New York, and the American Dream (Baltimore: Johns Hopkins University Press, 2014).

34. Richard Wade, "An Agenda for Urban History," in The State of American History, ed. Herbert J. Bass (Chicago: Quadrangle Books, 1970), 43-69.

\title{
Author Biography
}

Timothy J. Gilfoyle is professor of history at Loyola University Chicago and author of A Pickpocket's Tale: The Underworld of Nineteenth-Century New York (Norton, 2006); City of Eros: New York City, Prostitution, and the Commercialization of Sex, 1790-1920 (Norton, 1992); and Millennium Park: Creating a Chicago Landmark (University of Chicago Press and the Chicago History Museum, 2006). He is currently president of the Urban History Association.

\section{Notes on a Desegregated \\ Method: Learning from Michael Katz and Others}

\author{
N. D. B. Connolly' \\ DOI: 10.1 I77/0096/442/5579382
}

\section{Keywords}

Michael B. Katz, Segregation, Liberalism, Political Economy, The Academy

I was heartened, if surprised, to see Michael Katz's sunny assessment of our current scholarly moment: "As a field, urban history has never shimmered so vibrantly."1 I could not agree more.

'Department of History, Johns Hopkins University, Baltimore, MD, USA

\section{Corresponding Author:}

N. D. B. Connolly, Department of History, Johns Hopkins University, 30I Gilman Hall, 3400 N. Charles Street, Baltimore, MD 21218 , USA.

Email: nconnol2@jhu.edu 